\title{
Characterization of Corn Landraces Planted Grown in the Campos Gerais Region (Paraná, Brazil) for Industrial Utilization
}

\author{
Alessandra Teixeira Barbosa Pinto $^{1}$, Joyce Pereira $^{2}$, Tatiana Roselena de Oliveira ${ }^{1}$, \\ Rosilene Aparecida Prestes ${ }^{1}$, Rodrigo Rodrigues Mattielo ${ }^{3}$ and Ivo Mottin Demiate ${ }^{1 *}$ \\ ${ }^{1}$ Universidade Estadual de Ponta Grossa; Avenida Carlos Cavalcanti, 4748; 84030-900; Ponta Grossa - PR - \\ Brasil. ${ }^{2}$ Curso de Engenharia de Alimentos, ${ }^{3}$ Pós-Graduação em Agronomia.
}

\begin{abstract}
This work has the objective of characterizing twenty corn landraces grown in the Campos Gerais region (Paraná State) in relation to its chemical composition (moisture, ash, protein, ether extract, dietary fiber and starch) and physical properties (weight of 1000 grains, real density, flotation index, granulometry and color). In addition, also the lab scale processing of the kernels from the varieties was carried out for producing starch; starch purity was evaluated by measuring its protein contamination. Amylose contents and viscoamylograph profile were also evaluated. The results showed that the evaluated landraces have differences in chemical composition as well as in pericarp/endosperm/germ proportions and consequently it should have different industrial applications and interest for plant breeding.
\end{abstract}

Key words: maize landraces, chemical composition, starch, physical properties, rapid viscoanalyzer

\section{INTRODUCTION}

Corn (Zea mays, L.) is one of the main cultivated cereals all around the world. Its economic importance is due to many different ways of utilization from animal feeding to high technology industry (Cruz et al., 2006). Although corn kernels have not an expressive importance in direct human diet, several corn products are relevant for people of low income regions.

The main parts of corn kernel are the endosperm, pericarp and the germen. Each fraction presents distinct chemical composition and the quality is dependent from the genetic material as well as from the environment conditions.
The quality of corn for food and feed is different and genetic seems to be the best way of achieving the desired characteristics. The fast evolution of biotechnology made it possible to produce many kinds of hybrids with improved yield and other interesting characteristics (Trindade, 2006). The new biotechnology approach has many advantages in comparison to traditional technologies being able to introduce characteristics that reduce risks in agriculture. As many plant breeding programs are in development, each year several new genetic materials are marketed including dozens of corn hybrids. In Brazil there are many kinds of climatic, soil and environmental conditions due to its continental extension and important differences

\footnotetext{
*Author for correspondence: demiate@yahoo.com
} 
occur among the different geographical regions, including technical, economical, cultural and social aspects (Schmildt; Krause \& Cruz, 2006). In this way, it is essential that plant breeders be very aware to select the correct materials for the distinct national conditions.

In this corn breeding process the landraces are of great interest (Miranda et al., 2007) for identifying the needs of the farmers and exploiting their genetic variability. The landraces have potential in contributing with desired characteristics of cultivated plants including resistance to diseases and agricultural pests, improving crops and food safety (Fowler \& Hodgkin, 2004, Birol; Villalba \& Smale, 2007).

Several evidences show the importance of rescuing landraces for knowing their variability in terms of chemical composition of their edible parts and other economical interesting characteristics for industrial utilization as well as for breeding programs.

\section{MATERIALS AND METHODS}

\section{Material}

Representative samples of 20 corn landraces (Table 1) were grown in randomized blocks with four repetitions. The experiment was conducted at the School Farm of Universidade Estadual de Ponta Grossa, in Ponta Grossa, Paraná. The sowing was made in November/2006 and the harvest in March/2007. The sowing fertilization was made with $300 \mathrm{~kg} \mathrm{ha}^{-1}$ of the 5-25-25 (NPK) formulation. A complimentary fertilization was made 45 days after germination with urea $(100 \mathrm{~kg}$ $\mathrm{ha}^{-1}$ of nitrogen). The corn kernels were milled in a rotor mill (Tecnal model TE-633, Piracicaba, SP, Brazil) adjusted for fine milling and the granulometry of the milled product was evaluated with a Bertel (Caieiras, SP, Brazil) system of vibrating sieves.

Table 1 - Identification, common denomination, local of origin, city/state where the landraces were collected or bought.

\begin{tabular}{|c|c|c|c|}
\hline Number & Races & Local of origin & City/State \\
\hline 1 & Nutricional $n^{\circ} 61$ & Colônia Cachoeira & Rio Azul - PR \\
\hline 2 & Milho Grande no 52 & Roça Velha & Itaiacoca - P. Grossa - PR \\
\hline 3 & Milho Palha Roxa $n^{\circ} 72$ & Colônia Cachoeira & Rio Azul - PR \\
\hline 4 & Milho Paiol no 49 & Colônia Barra Bonita & Prudentópolis - PR \\
\hline 5 & Milho Branco $\mathrm{n}^{\circ} 57$ & Rio Azul de Cima & Rio Azul - PR \\
\hline 6 & Asteca $n^{\circ} 60$ & Colônia Cachoeira & Rio Azul - PR \\
\hline 7 & Caiano $n^{\circ} 63$ & Rio Vinagre & Rio Azul - PR \\
\hline 8 & Roxo Índio I n 60 & Pelotas & Pelotas - RS \\
\hline 9 & Milho Branco para Palha $n^{\circ} 69$ & Colônia Cachoeira & Rio Azul - PR \\
\hline 10 & Milho Pérola ${ }^{\circ} 65$ & Salto Braço do Potingá & Rio Azul - PR \\
\hline 11 & Carioca $n^{\circ} 68$ & Pinhalzinho & Rio Azul - PR \\
\hline 12 & Milho Astequinha Sabugo Fino $n^{\circ} 70$ & Marumbi dos Ribeiros & Rio Azul - PR \\
\hline 13 & Milho Vintenv $n^{\circ} 56$ & Porto Soares & Rio Azul - PR \\
\hline 14 & Milho Palha Roxa no 64 & Invernada & Rio Azul - PR \\
\hline 15 & Milho Encantilado n ${ }^{\circ} 59$ & Rio Vinagre & Rio Azul - PR \\
\hline 16 & Milho Branco $\mathrm{n}^{\circ} 62$ & Lajeado & Rio Azul - PR \\
\hline 17 & Milho Amarelo Antigo no 71 & Porto Soares & Rio Azul - PR \\
\hline 18 & Crioulo Oito Carreiras n ${ }^{\circ} 41$ & FEPAGRO & $\mathrm{RS}$ \\
\hline 19 & Crioulo Pururuca $n^{\circ} 38$ & FEPAGRO & $\mathrm{RS}$ \\
\hline 20 & Caiano Rajado no 16 & Pelotas & Pelotas - RS \\
\hline
\end{tabular}

\section{Chemical composition}

The chemical characterization of corn kernels included the following analyses: moisture content (AOAC, 2000, 925.10), protein (AOAC, 2000, 920.87), ash (AOAC, 2000, 923.03), lipids (IAL, 1985), starch (Demiate et al., 2001) and dietary fiber (AOAC, 2000, 985.29).

\section{Physical properties}

The weight of 1000 kernels of each sample was made as described by Mauricio et al., 2004).

The real density was evaluated as described by Mizuma, Kiyokawa \& Wakai (2008), by using a pycnometer of known mass that was completely filled with xylene and weighed. A pre established 
corn kernel weight was put into the pycnometer and xylene was used for completely filling the empty spaces among the kernels. The total weight was registered and used for calculations.

The flotation index was evaluated (Lojano-Alejo et al., 2007) by using a sodium nitrate solution (41 $\mathrm{g}$ in $100 \mathrm{~mL}$ of water) with a known density of $1.25 \mathrm{~g} \mathrm{dm}^{-3}$ at $23{ }^{\circ} \mathrm{C}$. The kernels were put in this solution that was stirred. After resting for one minute, the floating kernels were counted. The hardness classification was based on a scale proposed by Salinas; Bustos \& Gómez (1992), with floating index (FI) between 0 and $12 \%$ for very hard, 13 to $37 \%$ for hard, 38 to $62 \%$ for intermediary hard, 63 to $87 \%$ for soft and higher than $87 \%$ for very soft kernels.

\section{Starch extraction}

The starch extraction was made following the method of Ji, Seetharaman \& White (2004), with some adaptations. For extracting starch, 100 kernels were used, being 25 of each block. There was removal of impurities and damaged kernels. Steeping started when the kernels were put into 40 $\mathrm{mL}$ of a $1 \%$ sodium metabisulphite solution at $45^{\circ} \mathrm{C}$ for $72 \mathrm{~h}$, followed by manual pericarp and germen removal. The endosperm fraction was put into $30 \mathrm{~mL}$ of distilled water and finely ground. This suspension was centrifuged for $10 \mathrm{~min}$ at $3,200 \mathrm{rpm}$ for accelerating starch separation. The pellet was recovered and mixed with excess of a $0.1 \% \mathrm{NaOH}$ solution, in graduated cylinders for making precipitation fast. These cylinders were cooled to around $4{ }^{\circ} \mathrm{C}$ for $24 \mathrm{~h}$. The sediment was passed through a 325 mesh sieve, washing with distilled water. For neutralizing the sediment starch, addition of a $0.1 \% \mathrm{HCl}$ solution was made followed by distilled water washings until $\mathrm{pH}$ reached 6.0 - 7.0. The purified starch was then recovered by using a vacuum filtration system. The starch was dried for $24 \mathrm{~h}$ in a circulating oven at $45^{\circ} \mathrm{C}$ until constant weight.

\section{Starch characterization}

All starch samples extracted from the corn kernels were stored in a dessicator for moisture stabilization. The analyses were made with two repetitions.

\section{Properties of the starch pastes}

The starch pastes of the 20 different starch samples were made by employing a Rapid Viscoanalyzer (RVA 4, Newport Scientific,
Warriewood, Australia) using the STD1 profile of the software Thermocline. The data shown in the results are average of two repetitions. Starch slurries at $8.0 \%$ (14.0\% moisture basis) were analyzed, considering a final slurry weight of $28 \mathrm{~g}$.

\section{Statistical analysis}

The results were analyzed by the ANOVA followed by the Tukey test at $95 \%$ confidence level. These analyses were made using the ASSISTAT version 7.1 beta software (Silva, 2004). A correlation matrix was also built up in order to better discuss the results, employing the Statistica version 5.0 software, considering $95 \%$ confidence level. The principal component analysis (PCA) was employed in order to extract information from the results, using the Pirouette version 4.11 software (Infometrix). The auto scaling processing of the data was used for producing better results.

\section{RESULTS AND DISCUSSION}

The raw results are presented in the Table 2. The results showed that for moisture and ash contents, there were no significant differences at $95 \%$ of confidence. The average values of moisture ranged from $10.29 \%$ (Milho Grande $n^{\circ} 52$ ) to $11.45 \%$ (Milho Encantilado $\mathrm{n}^{\circ}$ 59). Other published papers (Luchin; Barcaccia and Parrini, 2003; Gonçalves et al., 2003) revealed results of ash of $1.56 \%$ and $1.27 \%$ in corn landraces and hybrids, respectively. The ANOVA showed significant difference for the protein levels among the varieties. The variety Crioulo Oito Carreiras $\mathrm{n}^{\circ} 41$ had the higher protein level $(12.41 \%)$, whereas the variety Caiano Rajado $\mathrm{n}^{\circ} 16$ had the lower $(10.26 \%)$. In the literature some authors reported that the protein contents for corn landraces were between 10.47 to $12.17 \%$ (Câmara, 2005), and in hybrids from 7.77 to $13.84 \%$ (Jiang et al., 2007). The average value found for dietary fiber was of 13.0 $\%$ and for starch this value was of $60.54 \%$. Other reports stated that starch contents in corn landraces were from 67.2 \% (Câmara, 2005) to more than $70.0 \%$ (Seetharaman et al., 2001).

\section{Starch extraction}

Table 3 shows the proportions of the morphological parts of corn kernel. The pericarp fraction varied from 3.73 to $7.38 \%$, whereas the germ fraction was between 7.05 to $12.92 \%$. In 
other reports where commercial corn hybrids were evaluated the germ percentages were of $5.75 \%$ (Dowd, 2003), $6.20 \%$ (Fox et al., 1992) and 6.97 $\%$ (Lopes-Filho, 1997). The Milho Paiol no49 had the higher endosperm percentage $(86.97 \%)$ and high starch extraction yield (39.87\%). On the other hand, the Asteca $\mathrm{n}^{\circ} 60$ had the lower value $(81.50 \%)$ and one of the lowest starch extraction yield $(20.22 \%)$.

Table 2 - Physicochemical composition and physical properties of corn landrace kernels.

\begin{tabular}{|c|c|c|c|c|c|c|c|c|c|c|c|c|}
\hline RACES & $\begin{array}{c}\text { MOS } \\
(\%)\end{array}$ & $\underset{(\%)}{\mathrm{ASH} *}$ & $\begin{array}{c}\text { PRO* } \\
(\%)\end{array}$ & $\begin{array}{l}\text { LIP * } \\
(\%)\end{array}$ & $\begin{array}{l}\text { STA * } \\
(\%)\end{array}$ & $\begin{array}{l}\text { DF * } \\
(\%)\end{array}$ & $\underset{(\mathrm{g})}{\mathbf{T K W}}$ * & $\begin{array}{c}\text { DR }(\text { g.cm } \\
3 \text { ) }\end{array}$ & $\begin{array}{l}\text { FI } \\
(\%)\end{array}$ & $\begin{array}{c}\text { COA } \\
(\%)\end{array}$ & $\begin{array}{l}\text { INT } \\
(\%)\end{array}$ & $\begin{array}{l}\text { FIN } \\
(\%)\end{array}$ \\
\hline Nutricional $n^{\circ} 61$ & $82 \mathrm{a}$ & $.42 \mathrm{a}$ & $11.04 \mathrm{ab}$ & $.68 \mathrm{ab}$ & $66.51 \mathrm{a}$ & $13.58 \mathrm{abcd}$ & $307.60 \mathrm{hi}$ & $1.265 \mathrm{a}$ & $31.0 \mathrm{bcd}$ & $25.55 \mathrm{cde}$ & $25.61 \mathrm{abcd}$ & $0.93 \mathrm{a}$ \\
\hline Milho Grande $n^{\circ} 52$ & $10.29 \mathrm{a}$ & $1.47 \mathrm{a}$ & $11.58 \mathrm{ab}$ & $4.60 \mathrm{abc}$ & 54.86 cde & $13.79 \mathrm{abcd}$ & $398.53 \mathrm{abc}$ & $1.262 \mathrm{a}$ & $39.0 \mathrm{abcd}$ & $23.67 \mathrm{de}$ & $27.97 \mathrm{ab}$ & $0.68 \mathrm{a}$ \\
\hline Milho Palha Roxa n ${ }^{\circ} 72$ & $11.17 \mathrm{a}$ & $1.51 \mathrm{a}$ & $10.32 \mathrm{~b}$ & $3.70 \mathrm{~cd}$ & $67.10 \mathrm{a}$ & $13.36 \mathrm{abcd}$ & 340.44 defghi & $1.257 \mathrm{a}$ & $27.0 \mathrm{~d}$ & $22.54 \mathrm{e}$ & $28.89 \mathrm{a}$ & $0.68 \mathrm{a}$ \\
\hline Milho Paiol n'49 & $.08 \mathrm{a}$ & $1.55 \mathrm{a}$ & $10.69 \mathrm{~b}$ & $4.32 \mathrm{abcd}$ & $65.22 \mathrm{ab}$ & $17.21 \mathrm{ab}$ & 320.36 fghi & $1.248 \mathrm{a}$ & $52.5 \mathrm{abc}$ & 27.48 abcde & 24.30 abcde & $0.49 \mathrm{a}$ \\
\hline Milho Branco $\mathrm{n}^{\mathrm{o}^{\circ}} 57$ & $10.89 \mathrm{a}$ & $1.56 \mathrm{a}$ & $10.88 \mathrm{ab}$ & $3.73 \mathrm{~cd}$ & 55.74 bcde & $18.08 \mathrm{a}$ & 362.51 bcdefgh & $1.225 \mathrm{a}$ & $60.5 \mathrm{a}$ & $24.51 \mathrm{cde}$ & $27.36 \mathrm{abc}$ & $0.36 \mathrm{a}$ \\
\hline Asteca $n^{\circ} 60$ & $10.63 \mathrm{a}$ & $1.48 \mathrm{a}$ & $10.99 \mathrm{ab}$ & $4.98 \mathrm{a}$ & 59.26 abcde & $13.85 \mathrm{abcd}$ & $317.66 \mathrm{ghi}$ & $1.307 \mathrm{a}$ & $31.5 \mathrm{bcd}$ & $28.44 \mathrm{abcd}$ & 23.76 abcde & $0.68 \mathrm{a}$ \\
\hline Caiano $n^{\circ} 63$ & $.17 \mathrm{a}$ & $1.48 \mathrm{a}$ & $10.54 \mathrm{~b}$ & $4.33 \mathrm{abcd}$ & $63.88 \mathrm{abcd}$ & $15.06 \mathrm{abc}$ & 340.52 defghi & $1.287 \mathrm{a}$ & $28.5 \mathrm{~cd}$ & $28.52 \mathrm{abcd}$ & 22.85 bcde & $0.45 \mathrm{a}$ \\
\hline Roxo Índio I n ${ }^{\circ} 60$ & $11.03 \mathrm{a}$ & $1.50 \mathrm{a}$ & $11.04 \mathrm{ab}$ & $4.32 \mathrm{abcd}$ & $63.24 \mathrm{abcd}$ & $12.60 \mathrm{bcd}$ & 380.69 bcde & $1.280 \mathrm{a}$ & $38.5 \mathrm{abcd}$ & 26.96 bcde & 24.78 abcde & $0.40 \mathrm{a}$ \\
\hline Milho Branco para Palha $n^{\circ} 69$ & $10.99 \mathrm{a}$ & $1.43 \mathrm{a}$ & $11.64 \mathrm{ab}$ & $4.15 \mathrm{abcd}$ & 62.14 abcde & $10.88 \mathrm{~cd}$ & 342.40 cdefghi & $1.272 \mathrm{a}$ & $30.0 \mathrm{bcd}$ & $31.67 \mathrm{ab}$ & $19.90 \mathrm{de}$ & $0.71 \mathrm{a}$ \\
\hline Milho Pérola n ${ }^{\circ} 65$ & $11.19 \mathrm{a}$ & $1.46 \mathrm{a}$ & $10.86 \mathrm{ab}$ & $4.56 \mathrm{abcd}$ & 58.77 abcde & $14.42 \mathrm{abcd}$ & $303.44 \mathrm{i}$ & $1.320 \mathrm{a}$ & $28.0 \mathrm{~d}$ & $32.49 \mathrm{a}$ & $19.03 \mathrm{e}$ & $0.49 \mathrm{a}$ \\
\hline Carioca $n^{\circ} 68$ & $11.18 \mathrm{a}$ & $1.52 \mathrm{a}$ & $10.63 \mathrm{~b}$ & $4.51 \mathrm{abcd}$ & 59.17 abcde & $12.97 \mathrm{bcd}$ & 377.03 bcdef & $1.268 \mathrm{a}$ & $27.5 \mathrm{~d}$ & $28.67 \mathrm{abcd}$ & 23.38 abcde & $0.31 \mathrm{a}$ \\
\hline Milho Astequinha Sabugo F & $11.06 \mathrm{a}$ & $1.55 \mathrm{a}$ & $11.62 \mathrm{ab}$ & $4.58 \mathrm{abcd}$ & $54.00 \mathrm{de}$ & $16.97 \mathrm{ab}$ & 325.99 efghi & $1.277 \mathrm{a}$ & $25.0 \mathrm{~d}$ & $29.57 \mathrm{abc}$ & 22.09 bcde & $0.35 \mathrm{a}$ \\
\hline Milho Vinten $n^{\circ} 56$ & $10.99 \mathrm{a}$ & $1.39 \mathrm{a}$ & $11.45 \mathrm{ab}$ & $4.41 \mathrm{abcd}$ & 59.89 abcde & $15.27 \mathrm{abc}$ & $308.91 \mathrm{hi}$ & $1.286 \mathrm{a}$ & $29.5 \mathrm{~cd}$ & $28.20 \mathrm{abcd}$ & 23.61 abcde & $0.46 \mathrm{a}$ \\
\hline Milho Palha Roxa no 64 & $11.35 \mathrm{a}$ & $1.53 \mathrm{a}$ & $11.23 \mathrm{ab}$ & $4.58 \mathrm{abcd}$ & 62.36 abcde & $15.25 \mathrm{abc}$ & $410.49 \mathrm{ab}$ & $1.263 \mathrm{a}$ & $37.5 \mathrm{abcd}$ & $28.64 \mathrm{abcd}$ & 23.49 abcde & $0.39 \mathrm{a}$ \\
\hline Milho Encantilado $\mathrm{n}^{\circ} 59$ & $11.45 \mathrm{a}$ & $1.54 \mathrm{a}$ & $10.92 \mathrm{ab}$ & $4.02 \mathrm{bcd}$ & 59.21 abcde & $13.64 \mathrm{abcd}$ & $386.91 \mathrm{bcd}$ & $1.216 \mathrm{a}$ & $54.0 \mathrm{ab}$ & $30.00 \mathrm{abc}$ & $21.67 \mathrm{cde}$ & $0.41 \mathrm{a}$ \\
\hline Milho Branco n 62 & $10.67 \mathrm{a}$ & $1.48 \mathrm{a}$ & $10.67 \mathrm{~b}$ & $3.63 \mathrm{~d}$ & $64.88 \mathrm{abc}$ & $14.08 \mathrm{abcd}$ & 371.32 bcdefg & $1.248 \mathrm{a}$ & $36.0 \mathrm{bcd}$ & $29.01 \mathrm{abcd}$ & 22.99 abcde & $0.35 \mathrm{a}$ \\
\hline Milho Amarelo Antigo $n^{\circ} 71$ & $10.82 \mathrm{a}$ & $1.56 \mathrm{a}$ & $11.15 \mathrm{ab}$ & 4.19 abcd & 58.68 abcde & $13.87 \mathrm{abcd}$ & 315.88 ghi & $1.262 \mathrm{a}$ & $35.5 \mathrm{bcd}$ & 26.49 bcde & $25.48 \mathrm{abcd}$ & $0.39 \mathrm{a}$ \\
\hline Crioulo Oito Carreiras n ${ }^{\circ} 41$ & $10.73 \mathrm{a}$ & $1.52 \mathrm{a}$ & $12.41 \mathrm{a}$ & $4.46 \mathrm{abcd}$ & $53.06 \mathrm{e}$ & $9.89 \mathrm{~d}$ & $450.28 \mathrm{a}$ & $1.299 \mathrm{a}$ & $26.5 \mathrm{~d}$ & 27.34 abcde & 24.29 abcde & $0.72 \mathrm{a}$ \\
\hline Crioulo Pururuca n ${ }^{\circ} 38$ & $11.14 \mathrm{a}$ & $1.47 \mathrm{a}$ & $10.87 \mathrm{ab}$ & $4.02 \mathrm{bcd}$ & 61.16 abcde & $11.70 \mathrm{~cd}$ & 355.48 bcdefghi & $1.237 \mathrm{a}$ & $45.5 \mathrm{abcd}$ & 27.91 abcde & 23.91 abcde & $0.23 \mathrm{a}$ \\
\hline Caiano Rajado no 16 & $11.38 \mathrm{a}$ & $1.46 \mathrm{a}$ & $10.26 \mathrm{~b}$ & $3.99 \mathrm{bcd}$ & 63.05 abcde & $11.49 \mathrm{~cd}$ & 347.49 cdefghi & $1.253 \mathrm{a}$ & $31.0 \mathrm{bcd}$ & $28.34 \mathrm{abcd}$ & 23.60 abcde & $0.22 \mathrm{a}$ \\
\hline & & 1.49 & & 4.29 & & 13.9 & & & & & & 0.48 \\
\hline Minimum & 10.29 & 1.39 & 10.26 & 3.63 & 53.06 & 9.89 & 303.44 & 1.216 & 25.01 & 22.54 & 19.03 & 0.22 \\
\hline Maximun & 11.45 & 1.56 & 12.41 & 4.98 & 67.1 & 18.08 & 450.28 & 1.32 & 60.5 & 32.49 & 28.89 & 0.93 \\
\hline Standard Deviation & 0.28 & 0.05 & 0.51 & 0.36 & 4.02 & 2.08 & 450.28 & 0.026 & 10.1 & 2.46 & 2.36 & 0.93 \\
\hline
\end{tabular}

MOS: Moisture, ASH: Ash, PRO: Protein, LIP: Lipids, DF: Dietary Fiber, STA: Starch, TKW: 1.000 kernel weight, RD: Real density, FI: Flotation Index, COA: Coarse particles $(850 \mu \mathrm{m}$ and $600 \mu \mathrm{m})$, INT: Intermediate particles $(250 \mu \mathrm{m}$ and $180 \mu \mathrm{m})$, FIN: Fine particles $(125 \mu \mathrm{m}$ and bottom).

* Dry weight bases

Values with similar letters in the same column do not differ significantly $(\mathrm{p}<0,05)$.

Table 3 - Fractions of the kernels and starch extraction yields.

\begin{tabular}{|c|c|c|c|c|}
\hline Races & Pericarp (\%) & $\operatorname{Germ}(\%)$ & Endosperm (\%) & Yield $(\%)$ \\
\hline Nutricional $n^{\circ} 61$ & 5.27 & 10.16 & 84.57 & 31.15 \\
\hline Milho Grande $\mathrm{n}^{\circ} 52$ & 6.18 & 11.10 & 82.72 & 33.02 \\
\hline Milho Palha Roxa n ${ }^{\circ} 72$ & 6.74 & 7.91 & 85.35 & 24.43 \\
\hline Milho Paiol n 49 & 5.98 & 7.05 & 86.97 & 39.87 \\
\hline Milho Branco n ${ }^{\circ} 57$ & 5.62 & 10.36 & 84.02 & 27.27 \\
\hline Asteca $\mathrm{n}^{\circ} 60$ & 5.57 & 12.92 & 81.50 & 20.22 \\
\hline Caiano ${ }^{\circ} 63$ & 5.46 & 9.99 & 84.55 & 35.00 \\
\hline Roxo Índio I n ${ }^{\circ} 60$ & 6.35 & 11.74 & 81.91 & 19.05 \\
\hline Milho Branco para Palha $n^{\circ} 69$ & 6.53 & 9.39 & 84.07 & 29.75 \\
\hline Milho Pérola n ${ }^{\circ} 65$ & 5.39 & 8.96 & 85.65 & 33.01 \\
\hline Carioca $\mathrm{n}^{\circ} 68$ & 6.76 & 11.17 & 82.07 & 27.96 \\
\hline Milho Astequinha Sabugo Fino ${ }^{\circ} 70$ & 6.73 & 11.69 & 81.59 & 32.44 \\
\hline Milho Vinten $n^{\circ} 56$ & 5.39 & 10.97 & 83.64 & 25.61 \\
\hline Milho Palha Roxa n ${ }^{\circ} 64$ & 5.67 & 10.16 & 84.17 & 35.22 \\
\hline Milho Encantilado n ${ }^{\circ} 59$ & 5.33 & 9.93 & 84.74 & 23.56 \\
\hline Milho Branco n ${ }^{\circ} 62$ & 6.20 & 9.38 & 84.43 & 30.21 \\
\hline Milho Amarelo Antigo n ${ }^{\circ} 71$ & 3.73 & 9.69 & 86.57 & 31.37 \\
\hline Crioulo Oito Carreiras n ${ }^{\circ} 41$ & 4.70 & 10.34 & 84.96 & 28.43 \\
\hline Crioulo Pururuca n ${ }^{\circ} 38$ & 5.73 & 10.22 & 84.05 & 35.95 \\
\hline Caiano Rajado n ${ }^{\circ} 16$ & 7.38 & 10.26 & 82.37 & 24.78 \\
\hline Average & 5.84 & 10.17 & 83.99 & 29.42 \\
\hline Minimum & 3.73 & 7.05 & 81.50 & 19.05 \\
\hline Maximum & 7.38 & 12.92 & 86.97 & 39.87 \\
\hline Standard Deviation & 0.82 & 1.31 & 1.57 & 5.40 \\
\hline
\end{tabular}




\section{Starch characterization}

In the Table 4 are shown the results of the analyses of extracted starch. The average protein content for the extracted starches was of $1.0 \%$, with a minimum of $0.52 \%$ (Milho Palha Roxa $\mathrm{n}^{\circ} 72$ ) and a maximum of $1.42 \%$ (Milho Amarelo Antigo $\mathrm{n}^{\circ}$ 71). Ji; Seetharaman, White (2004) found protein values for corn starches extracted in laboratory in the range of 2.82 to $3.65 \%$ and it should explain the higher extraction yields related in their report.
The apparent amylose contents of corn landrace starches did not differ at $95 \%$ confidence level and the average value was of $17.66 \%$, in a range from $13.14 \%$ (Milho Paiol $\mathrm{n}^{\circ} 49$ ) to $21.51 \%$ (Milho Astequinha Sabugo Fino $\mathrm{n}^{\mathrm{0}} 70$ ). In the case of total amylose, there was statistical difference among the starches. The average amylose content was of $25.59 \%$, in a range of $19.10 \%$ (Roxo Índio $\mathrm{I}^{\mathrm{o}} 60$ ) to $33.86 \%$ (Milho Palha Roxa ${ }^{\circ} 72$ ).

Table 4 - Hot paste viscosity, Peak viscosity, gelatinization temperature, final viscosity, breakdown and setback.

\begin{tabular}{|c|c|c|c|c|c|c|}
\hline Races & HPV (cP) & PV (cP) & $\mathbf{P}_{\text {onset }}\left({ }^{\circ} \mathbf{C}\right)$ & FV (cP) & $\begin{array}{c}\text { Breakdown } \\
\text { (cP) }\end{array}$ & $\begin{array}{c}\text { Setback } \\
(\mathbf{c P})\end{array}$ \\
\hline Nutricional $\mathrm{n}^{\circ} 61$ & 1248 a & $1818 \mathrm{ab}$ & 78.43 bcde & $1897 \mathrm{abc}$ & 794 bcdef & 873 bcd \\
\hline Milho Grande ${ }^{\circ} 52$ & 1036 bcde & $1795 \mathrm{ab}$ & $77.63 \mathrm{efg}$ & $1836 \mathrm{abc}$ & 808 bcdef & 849 bcd \\
\hline Milho Palha Roxa nº72 & 991 bcde & $1804 \mathrm{ab}$ & $77.55 \mathrm{fg}$ & $1793 \mathrm{abc}$ & 867 abcd & $857 \mathrm{bcd}$ \\
\hline Milho Paiol n49 & 1008 bcde & $1550 \mathrm{e}$ & 78.45 bcde & $1578 \mathrm{bc}$ & 715 efgh & $743 \mathrm{~cd}$ \\
\hline Milho Branco $\mathrm{n}^{\mathrm{o}^{\circ}} 57$ & $904 \mathrm{de}$ & $1398 \mathrm{fg}$ & $78.50 \mathrm{bcd}$ & $1593 \mathrm{bc}$ & $568 \mathrm{i}$ & $763 \mathrm{~cd}$ \\
\hline Asteca $n^{\circ} 60$ & $1108 a b c$ & $1808 \mathrm{ab}$ & $80.85 \mathrm{a}$ & 1940 a & 759 defg & $891 \mathrm{abc}$ \\
\hline Caiano $\mathrm{n}^{\circ} 63$ & 968 bcde & $1726 \mathrm{bc}$ & 78.40 bcdef & $1714 a b c$ & 813 bcdef & $801 \mathrm{bcd}$ \\
\hline Roxo Índio I no 60 & 957 cde & $1808 \mathrm{ab}$ & 78.43 bcde & 1985 a & $900 \mathrm{abc}$ & $1078 \mathrm{a}$ \\
\hline Milho Branco para Palha no 69 & 939 cde & $1317 \mathrm{~g}$ & $81.33 \mathrm{a}$ & $1581 \mathrm{bc}$ & $425 j$ & $689 \mathrm{~d}$ \\
\hline Milho Pérola n ${ }^{\circ} 65$ & 875 e & $1785 \mathrm{ab}$ & $78.53 \mathrm{bc}$ & $1802 \mathrm{abc}$ & $964 \mathrm{a}$ & $981 \mathrm{ab}$ \\
\hline Carioca $\mathrm{n}^{\circ} 68$ & 1005 bcde & $1750 \mathrm{~b}$ & $78.83 \mathrm{~b}$ & $1799 \mathrm{abc}$ & 800 bcdef & 849 bcd \\
\hline Milho Astequinha Sabugo Fino $\mathrm{n}^{\circ} 70$ & 1044 bcde & $1764 \mathrm{~b}$ & 78.43 bcde & $1902 \mathrm{abc}$ & 764 cdefg & $903 a b c$ \\
\hline Milho Vinten $n^{\circ} 56$ & 1066 bcd & $1790 \mathrm{ab}$ & 78.45 bcde & $1907 \mathrm{ab}$ & 782 bcdef & 899 abc \\
\hline Milho Palha Roxa n 64 & 982 bcde & $1700 \mathrm{bcd}$ & 78.48 bcde & $1719 a b c$ & 831 abcde & $800 \mathrm{bcd}$ \\
\hline Milho Encantilado n ${ }^{\circ} 59$ & 1015 bcde & $1571 \mathrm{de}$ & $77.65 \mathrm{defg}$ & $1753 a b c$ & $606 \mathrm{hi}$ & $788 \mathrm{~cd}$ \\
\hline Milho Branco no 62 & 970 bcde & 1495 ef & 78.08 bcdef & $1754 a b c$ & 630 ghi & $840 \mathrm{bcd}$ \\
\hline Milho Amarelo Antigo no 71 & $1061 \mathrm{bcd}$ & 1908 a & $75.95 \mathrm{i}$ & $1755 a b c$ & $909 \mathrm{ab}$ & $756 \mathrm{~cd}$ \\
\hline Crioulo Oito Carreiras $\mathrm{n}^{\circ} 41$ & 997 bcde & $1783 \mathrm{ab}$ & $76.83 \mathrm{gh}$ & $1844 \mathrm{abc}$ & 841 abcde & $902 \mathrm{abc}$ \\
\hline Crioulo Pururuca ${ }^{\circ} 38$ & 920 de & $1705 \mathrm{bcd}$ & $76.05 \mathrm{hi}$ & $1572 \mathrm{c}$ & 834 abcde & $701 \mathrm{~d}$ \\
\hline Caiano Rajado $\mathrm{n}^{\circ} 16$ & $1129 a b$ & 1608 cde & 77.75 cdef & $1700 \mathrm{abc}$ & 691 fghi & $783 \mathrm{~cd}$ \\
\hline Average & 1011 & 1693.98 & 78.22 & 1771.13 & 764.93 & 837.08 \\
\hline Minimun & 875 & 1317 & 75.95 & 1571.5 & 425 & 689 \\
\hline Maximun & 1247.5 & 1908 & 81.33 & 1985.5 & 963.5 & 1077.5 \\
\hline Standard Deviation & 85.24 & 155.04 & 1.27 & 124.55 & 128.99 & 93.29 \\
\hline
\end{tabular}

$\mathrm{P}_{\text {onset }}$ : gelatinization temperature; HPV: hot paste viscosity, PV: peak viscosity, FV: final viscosity

Values are average of duplicate runs

Values with similar letters in the same column do not differ significantly $(\mathrm{p}<0,05)$.

The viscoamylographic pattern is presented in Table 4 with the main points of the analysis (viscosity peak, hot paste viscosity, final viscosity, breakdown, setback and gelatinization temperature). The profile is typical for most of the starch samples, the final viscosity is high due to retrogradation and the paste is relatively stable to stirred cooking, when comparing with cassava starch (Schoch \& Maywald, 1968; Cereda et al., 2001), for example.

For some samples there were lower values of final viscosities when compared to viscosity peaks. The samples that had this viscoamylographic pattern were Milho Palha Roxa $\mathrm{n}^{\circ} 72$, Caiano $\mathrm{n}^{\circ}$ 63, Milho Amarelo Antigo $\mathrm{n}^{\mathrm{o}} 71$ and Crioulo Pururuca $\mathrm{n}^{\circ} 38$. For the Amarelo Antigo $\mathrm{n}^{\circ} 71$ and Crioulo Pururuca $\mathrm{n}^{\mathrm{o}} 38$ varieties, this pattern should be 
associated with the low levels of total amylose (23.85 and $21.91 \%$, respectively) that reduce final viscosity (Salgo \& Juhász, 2008; Blazek, 2008). The Milho Palha Roxa $\mathrm{n}^{\circ} 72$ and Caiano $\mathrm{n}^{\circ} 63$ varieties had high lipid complexed amylose levels (13.18 and $10.14 \%$, respectively), what have direct influence on viscosity. As written by Nelles et al., (2000), a small amount of lipids or phospholipids in starch affects the paste properties. Starch has free fatty acids and phospholipids in amounts directly related with amylose, distributed asymmetrically in the granules.

\section{Correlation analysis}

In the Table 5 the correlations among results are shown. The protein content had a negative correlation with starch content $(r=-0.66$, at $95 \%$ confidence level), in the same way as reported by Chander et al. (2008). Fox et al. (1992) also found this correlation for corn hybrids $(r=-0.63 ; \mathrm{p}<0.01)$. The hardness, as estimated by the flotation index, did not have correlation with the protein content, although some authors found positive correlation (Narváez-González et al., 2006), attributed to strong association between starch granules and protein with absence of empty intergranular spaces in the endosperm (Gibbon; Wang \& Larkins, 2003, Gibbon \& Larkins, 2005). Pereira et al. (2008) reported that corn kernels with hard or dent endosperms have abundance of organized protein bodies what explain the compact of these endosperms.

A positive correlation was observed between lipid content and kernel real density $(r=0.67$, at $95 \%$ of confidence). Although not expected this could be explained by a study for wheat of Scott (1951) cited by Posner (1985). The author reported that wheat germen had a real density of $1.34 \mathrm{~g} \mathrm{~cm}^{-3}$, very close to that of the whole grain, of $1.36 \mathrm{~g} \mathrm{~cm}^{-}$ ${ }^{3}$. In the germ, beyond lipids, there are important levels of protein and sugars, which explain the data reported by Posner (1985). Furthermore the studied corn landraces presented high percentage of germ from 7.0 to $12.0 \%$. As expected the germ percentage and lipid content were positively correlated ( $r=0.51,95 \%$ of confidence).

An expected negative correlation was found between flotation index and real density $(r=-0.74$, at $95 \%$ of confidence); this fact was already reported by Salinas; Bustos \& Gómez (1992), that found $\mathrm{r}=-0.94$, at $95 \%$ of confidence.

The granulometric profile evaluated by the percentage of coarse, intermediary and fine particles produced by corn kernels milling, revealed a negative correlation between coarse and intermediary particles $(\mathrm{r}=-0.93$, at $95 \%$ of confidence). The hardness classification of the grains allows understanding of this correlation. The hard endosperm kernels had higher percentage of coarse particles (retained in the $850 \mu \mathrm{m}$ and 600 $\mu \mathrm{m}$ sieves) (Milho Pérola $\mathrm{n}^{\circ}$ 65) and the kernels classified as intermediary that had particles between $250 \mu \mathrm{m}$ and $180 \mu \mathrm{m}$ of diameter (Milho Grande $\mathrm{n}^{\circ}$ 52). In this way, we expected to have a significant correlation between hardness and the particle size distribution, but this fact did not happen.

In the processing of corn grains for starch extraction, the correlations confirmed the expected results. There were negative correlations between germ and endosperm percentages and endosperm and pericarp percentages $(r=-0.85$ and $r=-0.55$, respectively, at $95 \%$ of confidence).

Starch extraction yield had a positive correlation with endosperm percentage $(\mathrm{r}=0.50$, at $95 \%$ of confidence) and negative with germ percentage $(\mathrm{r}=$ -0.49 , at $95 \%$ of confidence).

The apparent viscosity profile (viscoamylography) of the starches was influenced by some of the studied parameters. The flotation index correlated negatively with peak viscosity $(r=-0.48$, at $95 \%$ of confidence) and also with the final viscosity ( $r=$ -0.51 , at $95 \%$ of confidence). Corn varieties with low flotation index, classified in this work as hard corn (Salinas, Bustos \& Gómez, 1992), presented higher average values of final viscosity $(1799 \mathrm{cP})$, breakdown $(772 \mathrm{cP})$ and peak viscosity $(1719 \mathrm{cP})$. Seetharaman et al. (2001) when comparing starch paste properties of starches from corn with different hardness concluded that only very soft (floury) endosperms produced pastes with distinct characteristics. The starches from floury endosperms had higher gelatinization temperatures and lower values of peak viscosity, final viscosity, breakdown and setback. Due to this report, it would be expected that hard endosperms presented higher values for peak and final viscosity, breakdown and setback. The real density results confirmed this expectation as there was a positive correlation with viscosity peak $(\mathrm{r}=0.50)$, final viscosity $(\mathrm{r}=0.56)$, breakdown $(\mathrm{r}=0.48)$ and setback $(\mathrm{r}=0.60)$, always at $95 \%$ of confidence level. Almeida-Domingues; Suhendro \& Rooney 
(1997) reported that hard endosperm particles need more time for hydration and starch gelatinization for resulting in viscous pastes.

In relation to complexed amylose, negative correlations were found with final viscosity $(\mathrm{r}=$ $0.45)$ and setback $(\mathrm{r}=-0.46)$. This is discussed in other papers (Ribeiro \& Seravalli, 2004) that mention that lipids affect the setback as they form complexes with helicoidal amylose and make difficult water absorption in the granules. Jane et al. (1999) reported that the reduction in the viscosity peak is due to lipids and phospholipids complexation with amylose.

Wickramasinghe et al. (2009) studying starches from tuberous crops observed the influence of the granular swelling on peak viscosity and breakdown. These authors correlated positively breakdown with granular swelling and viscosity peak and stated that the bigger granules swollen more intensively. During stirred cooking, on the other hand, apparent viscosity dropped drastically. The corn starches from landraces of our study also presented a positive correlation between viscosity peak and breakdown $(\mathrm{r}=0.90)$, similar to the correlation found by Hou et al. (2008) ( $\mathrm{r}=0.89$; $P<0.01)$.
Other points of the viscoamylograms were correlated as peak and final viscosities $(r=0.70$, at $95 \%$ of confidence). This was expected as these points are interdependent.

The viscosity peak and the setback were positively correlated $(\mathrm{r}=0.56$, at $95 \%$ of confidence) due to amylose liberation during the starch granules swelling. Also the setback and the breakdown and the breakdown and the final viscosity were positively correlated $(r=0.55$ and $r=0.49$, respectively). Breakdown is an indicative of granular disruption related with amylose liberation. High concentrations of free amylose become available in the polymer solution and reassociate increasing the final viscosity (setback).

The gelatinization temperature and the breakdown presented a negative correlation ( $\mathrm{r}=-0.49$, at $95 \%$ of confidence), what could be due to the energetic demand for complete swelling of the granules. As the gelatinization temperature rises the granular swelling becomes difficult and limited and then the breakdown is lower. It is important to clarify that in this work we used the STD1 RVA profile and analysis is very short, taking only $13 \mathrm{~min}$ to be completed.

Table 5 - Correlation among the results of characterization of the grains and of the starches of 20 corn landraces.

\begin{tabular}{|c|c|c|c|c|c|c|c|c|c|c|c|c|c|c|c|c|c|c|c|c|c|c|c|c|c|c|c|c|}
\hline & MOS & ASH & PRO & $L I P$ & $S T A$ & $D F$ & TKW & $R D$ & $F I$ & $C O L$ & $C O A$ & $I N T$ & $F I N$ & PER & GER & $E N D$ & YIE & $\begin{array}{c}\text { PRO_S } \\
\text { TA }\end{array}$ & $\begin{array}{c}A M Y_{-} A \\
P\end{array}$ & $A M Y_{-} T$ & ${ }_{I P}^{A M Y_{-} L}$ & $\begin{array}{c}A M Y L \\
O\end{array}$ & $\begin{array}{c}\text { PONSE } \\
T\end{array}$ & $P V$ & $H P V$ & $F V$ & $B D$ & $S B$ \\
\hline MOS & 1 & & & & & & & & & & & & & & & & & & & & & & & & & & & \\
\hline$A S H$ & ns & 1 & & & & & & & & & & & & & & & & & & & & & & & & & & \\
\hline PRO & -0.45 & $\mathrm{~ns}$ & 1 & & & & & & & & & & & & & & & & & & & & & & & & & \\
\hline LIP & $\mathrm{ns}$ & $\mathrm{ns}$ & $\mathrm{ns}$ & 1 & & & & & & & & & & & & & & & & & & & & & & & & \\
\hline STA & ns & $\mathrm{ns}$ & -0.66 & ns & 1 & & & & & & & & & & & & & & & & & & & & & & & \\
\hline$D F$ & ns & $\mathrm{ns}$ & $\mathrm{ns}$ & ns & ns & 1 & & & & & & & & & & & & & & & & & & & & & & \\
\hline TKW & ns & $\mathrm{ns}$ & ns & ns & $\mathrm{ns}$ & ns & 1 & & & & & & & & & & & & & & & & & & & & & \\
\hline$R D$ & ns & $\mathrm{ns}$ & $\mathrm{ns}$ & 0.67 & ns & ns & $\mathrm{ns}$ & 1 & & & & & & & & & & & & & & & & & & & & \\
\hline$F I$ & ns & $\mathrm{ns}$ & ns & $\mathrm{ns}$ & $\mathrm{ns}$ & $\mathrm{ns}$ & $\mathrm{ns}$ & -0.74 & 1 & & & & & & & & & & & & & & & & & & & \\
\hline$C O L$ & ns & $\mathrm{ns}$ & ns & ns & $\mathrm{ns}$ & $\mathrm{ns}$ & $\mathrm{ns}$ & $\mathrm{ns}$ & ns & 1 & & & & & & & & & & & & & & & & & & \\
\hline $\mathrm{COA}$ & 0.46 & $\mathrm{~ns}$ & ns & $\mathrm{ns}$ & ns & ns & $\mathrm{ns}$ & $\mathrm{ns}$ & ns & $\mathrm{ns}$ & 1 & & & & & & & & & & & & & & & & & \\
\hline$I N T$ & $\mathrm{~ns}$ & ns & ns & $\mathrm{ns}$ & $\mathrm{ns}$ & $\mathrm{ns}$ & $\mathrm{ns}$ & ns & ns & $\mathrm{ns}$ & -0.93 & 1 & & & & & & & & & & & & & & & & \\
\hline FIN & $\mathrm{ns}$ & ns & ns & ns & ns & ns & ns & ns & ns & ns & ns & ns & 1 & & & & & & & & & & & & & & & \\
\hline PER & ns & ns & ns & ns & ns & ns & ns & ns & ns & ns & ns & $\mathrm{ns}$ & ns & 1 & & & & & & & & & & & & & & \\
\hline GER & ns & $\mathrm{ns}$ & ns & 0.51 & -0.46 & ns & $\mathrm{ns}$ & $\mathrm{ns}$ & $\mathrm{ns}$ & $\mathrm{ns}$ & $\mathrm{ns}$ & ns & ns & ns & 1 & & & & & & & & & & & & & \\
\hline END & $\mathrm{ns}$ & ns & ns & $\mathrm{ns}$ & $\mathrm{ns}$ & ns & $\mathrm{ns}$ & $\mathrm{ns}$ & $\mathrm{ns}$ & $\mathrm{ns}$ & $\mathrm{ns}$ & ns & ns & $-0,55$ & -0.85 & 1 & & & & & & & & & & & & \\
\hline YIE & ns & $\mathrm{ns}$ & ns & $\mathrm{ns}$ & $\mathrm{ns}$ & ns & $\mathrm{ns}$ & $\mathrm{ns}$ & ns & $\mathrm{ns}$ & ns & $\mathrm{ns}$ & $\mathrm{ns}$ & $\mathrm{ns}$ & -0.49 & 0.50 & 1 & & & & & & & & & & & \\
\hline PRO_STA & $\mathrm{ns}$ & $\mathrm{ns}$ & ns & ns & ns & $\mathrm{ns}$ & $\mathrm{ns}$ & $\mathrm{ns}$ & $\mathrm{ns}$ & $\mathrm{ns}$ & $\mathrm{ns}$ & $\mathrm{ns}$ & $\mathrm{ns}$ & ns & $\mathrm{ns}$ & ns & $\mathrm{ns}$ & 1 & & & & & & & & & & \\
\hline$A M Y_{-} A P$ & $\mathrm{~ns}$ & ns & ns & ns & ns & ns & $\mathrm{ns}$ & $\mathrm{ns}$ & -0.52 & $\mathrm{~ns}$ & $\mathrm{~ns}$ & ns & $\mathrm{ns}$ & ns & ns & $\mathrm{ns}$ & $\mathrm{ns}$ & $\mathrm{ns}$ & 1 & & & & & & & & & \\
\hline$A M Y_{-} T O$ & $\mathrm{~ns}$ & $\mathrm{~ns}$ & ns & ns & ns & ns & $\mathrm{ns}$ & $\mathrm{ns}$ & ns & $\mathrm{ns}$ & ns & ns & ns & ns & -0.48 & $\mathrm{~ns}$ & $\mathrm{~ns}$ & $\mathrm{~ns}$ & 0.59 & 1 & & & & & & & & \\
\hline AMIY_LIP & ns & $\mathrm{ns}$ & ns & ns & $\mathrm{ns}$ & ns & $\mathrm{ns}$ & $\mathrm{ns}$ & $\mathrm{ns}$ & $\mathrm{ns}$ & $\mathrm{ns}$ & ns & $\mathrm{ns}$ & ns & -0.65 & 0.51 & ns & ns & $\mathrm{ns}$ & 0.83 & 1 & & & & & & & \\
\hline AMYLO & $\mathrm{ns}$ & ns & ns & ns & ns & ns & $\mathrm{ns}$ & $\mathrm{ns}$ & $\mathrm{ns}$ & $\mathrm{ns}$ & $\mathrm{ns}$ & ns & ns & ns & 0.48 & ns & $\mathrm{ns}$ & ns & -0.59 & -1.00 & -0.83 & 1 & & & & & & \\
\hline Ponset & ns & $\mathrm{ns}$ & ns & $\mathrm{ns}$ & $\mathrm{ns}$ & ns & $\mathrm{ns}$ & $\mathrm{ns}$ & $\mathrm{ns}$ & ns & ns & $\mathrm{ns}$ & ns & ns & ns & ns & $\mathrm{ns}$ & ns & $\mathrm{ns}$ & ns & ns & $\mathrm{ns}$ & 1 & & & & & \\
\hline$P V$ & ns & ns & ns & 0.54 & $\mathrm{~ns}$ & ns & $\mathrm{ns}$ & 0.50 & -0.48 & -0.52 & $\mathrm{~ns}$ & ns & 0.50 & ns & $\mathrm{ns}$ & ns & $\mathrm{ns}$ & ns & $\mathrm{ns}$ & ns & ns & $\mathrm{ns}$ & $\mathrm{ns}$ & 1 & & & & \\
\hline$H P V$ & ns & $\mathrm{ns}$ & ns & $\mathrm{ns}$ & ns & ns & $\mathrm{ns}$ & $\mathrm{ns}$ & $\mathrm{ns}$ & $\mathrm{ns}$ & ns & ns & $\mathrm{ns}$ & ns & ns & $\mathrm{ns}$ & $\mathrm{ns}$ & ns & ns & $\mathrm{ns}$ & ns & ns & $\mathrm{ns}$ & $\mathrm{ns}$ & 1 & & & \\
\hline$F V$ & ns & ns & ns & 0.54 & $\mathrm{~ns}$ & ns & $\mathrm{ns}$ & 0.56 & -0.51 & $\mathrm{~ns}$ & $\mathrm{~ns}$ & $\mathrm{~ns}$ & 0.50 & ns & 0.60 & -0.47 & -0.53 & $\mathrm{~ns}$ & ns & ns & -0.45 & ns & $\mathrm{ns}$ & 0.70 & ns & 1 & & \\
\hline$B D$ & ns & ns & ns & $\mathrm{ns}$ & $\mathrm{ns}$ & ns & $\mathrm{ns}$ & 0.48 & ns & ns & $\mathrm{ns}$ & $\mathrm{ns}$ & ns & $\mathrm{ns}$ & ns & ns & ns & $\mathrm{ns}$ & ns & ns & ns & ns & -0.49 & 0.90 & ns & 0.49 & 1 & \\
\hline$S T$ & ns & ns & ns & ns & ns & $\mathrm{ns}$ & ns & 0.60 & ns & -0.46 & ns & $\mathrm{ns}$ & 0.46 & ns & ns & ns & -0.46 & $\mathrm{~ns}$ & ns & ns & -0.46 & ns & ns & 0.56 & ns & 0.86 & 0.55 & 1 \\
\hline
\end{tabular}

MOS: Moisture; ASH: Ash; PROT: Protein; LIP: Lipids; STA: Starch; DF: Dietary Fiber; TKW: 1.000 kernel weight; RD: Real density; FI: Flotation Index; COL: Color; COA: Coarse particles; INT: Intermediate particles; FIN: Fines particles; PER: Pericarp; GER: Germ; END: Endospern; YIE: Yield; PRO_STA: Protein Starch; AMY_AP: Apparent amylase; AMY_TO: Total amylase; AMY_LIP: Amylose-lipids complex; AMYLOP: Amylopectin; Ponset: Gelatinization temperature; PV: Viscosity pasting; HPV: Hot paste viscosity; FV: Final viscosity; BD: Breakdown and ST: Setback. 


\section{Principal component analysis (PCA)}

The PCA was used to explore the variability of samples considering the selected physicochemical and physical aspects of the grains and of their starches. For an initial analysis, all the variables were considered to check the degree of explained variance. By using ten factors the explained variance reached $92.29 \%$. The two first PC were responsible for explaining $36.06 \%$ (PC1 $=22.42$ $\%$ and $\mathrm{PC} 2=13.66 \%$ ) of total variance of the original data. For improving the variance explanation of the model, some variables were excluded: moisture, thousand kernels weight, color, total amylose, fine particles percentage and setback. With this next data the PCA with ten factors explained $96.22 \%$ of the total variance. The two first PCs explained $41.52 \%$ ( $\mathrm{PC} 1=25.58$ $\%$ and $\mathrm{PC} 2=16.84 \%)$ of total variance of the original data. The samples were grouped in the same manner as in the first PCA, with all variables.

The positive $\mathrm{PC} 1$, in the right side (Fig 1), is associated with the percentage of germ, lipids, real density, protein, intermediary size particles, breakdown, peak and hot paste viscosities and gelatinization temperature. In the left side of the PC1 are the variables starch, ash, dietary fiber, percentage of endosperm and of pericarp, starch yield and flotation index. This PC should be considered a dimension of endosperm density and hardness as the samples presenting higher real densities and lower flotation indexes are located in the positive side of the component. On the other hand, the less dense kernels presenting higher flotation indexes are located in the negative side of the PC1.

The PC2 was characterized by the particle size distribution, staying in one side that of coarse and in the other of intermediary granulometry. The grains that after milling produced higher amounts of coarse particles are located in the negative side of PC2 and the samples with higher amounts of intermediary size particles are in the positive side. As a consequence, these two variables allow a separation among grains with different hardness, as the varieties with proportionally more coarse particles have their endosperms classified as hard. In this way, the interaction of flotation index, real density, coarse and intermediary particles were responsible for the separation of the varieties in four groups (Fig 1) identified with numbers from 1 to 4 , in decreasing order of endosperm hardness. The group 1 is classified as low-intermediary hardness, as the samples presented higher flotation indexes, lower densities and higher percentage of intermediary particles. The group 4 , on the other hand, includes grains with higher densities, lower flotation indexes and higher percentage of coarse particles, being classified as hard.

Another grouping showed in Fig 1 includes the grains that presented higher percentage of germ and lipids in the positive side of PC1. This fact explains the correlation between real density and lipid content $(r=0.67$ at $95 \%$ of confidence).

Another PCA analysis was carried out considering only the main physicochemical results (protein, dietary fiber, lipids and starch contents) and the morphological fractions (endosperm, pericarp and germ percentages) of the corn landraces. In the Fig 2 the results clearly show that in the endosperm fraction is located the great part of starch, in the pericarp the fiber fraction and in the germ is rich in lipids and protein. This analysis allows the identification of two main groups in the corn landraces studied (Fig 3). The first group includes samples that have more endosperm and starch and are located at the negative side of the PC1 (varieties marked as 3 and 4). The second group (varieties marked as 2, 6, 12 and 18) is characterized by kernels with higher percentage of germ and consequently with more protein and lipids. The variety identified as 16 stayed between the two groups due to its intermediary chemical composition. The varieties with the higher levels of dietary fiber are those located in the center of the graph. The variety coded as 20 had higher percentage of pericarp and due to that is isolated in the upper part of the graph. The other samples, 8 , 11 and 13 are in between the groups separated by dietary fiber, lipids, protein and germ presenting intermediary values for these parameters. 


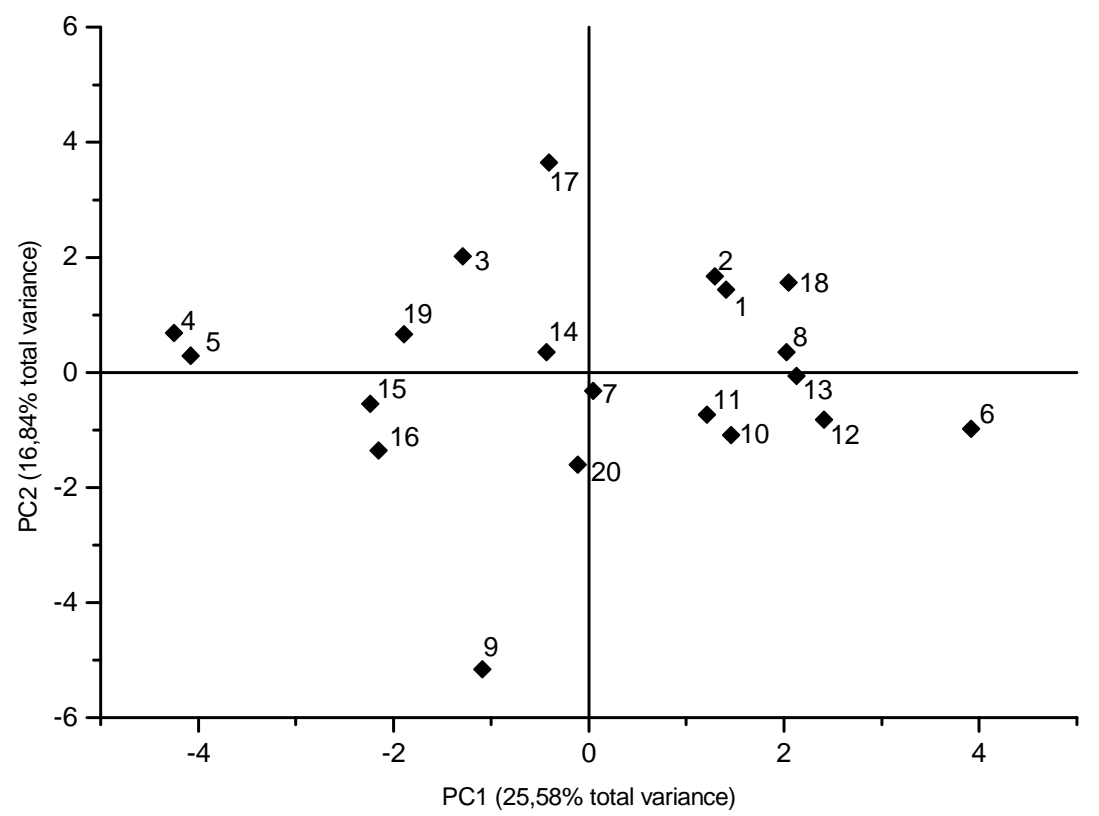

Figure 1 - Grouping of corn landraces according to their physicochemical and physical properties and their starches.

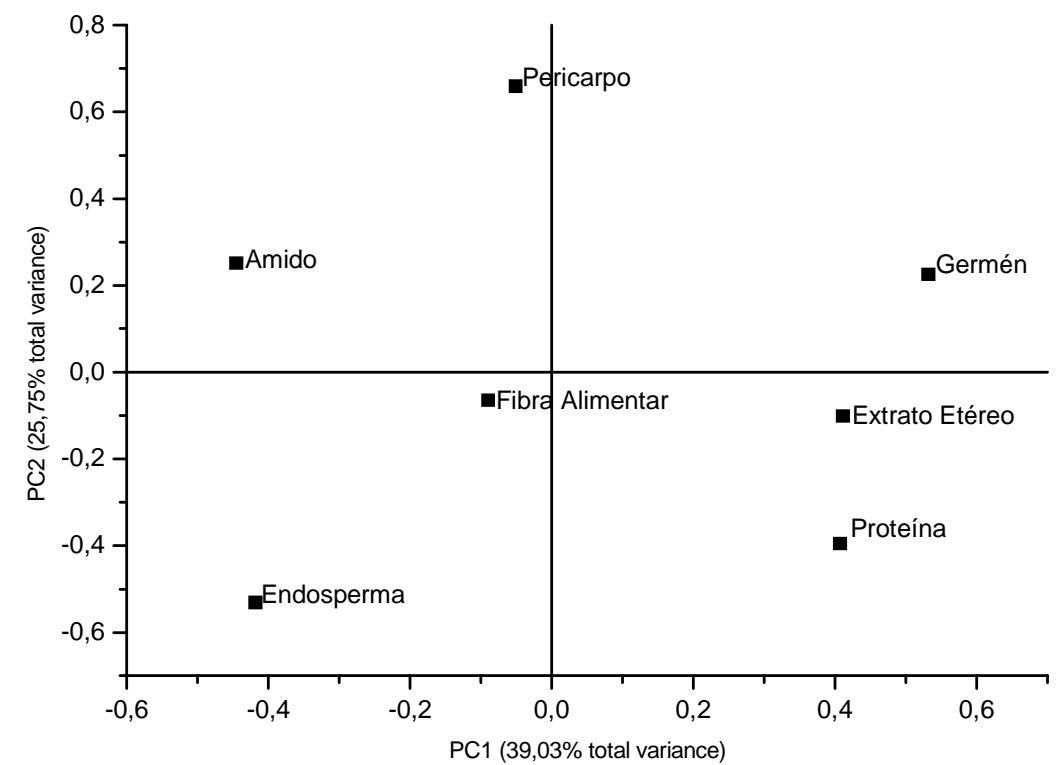

Figure 2 - Effect of the selected variables in the PCA analysis (loadings). 


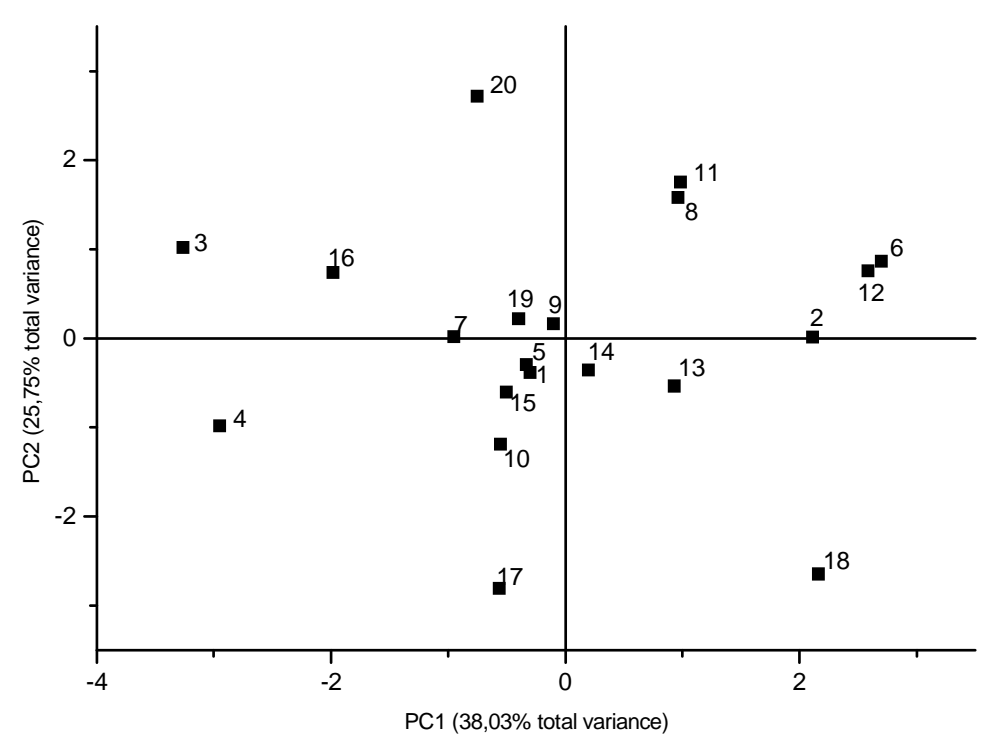

Figure 3 - Grouping of corn landraces by selected physicochemical characteristics and morphological fractions.

\section{CONCLUSION}

The corn landraces presented relatively high germ percentage and consequently high lipid contents. The physical properties of corn grains like flotation index, real density and particle size distribution are important parameters for classifying endosperm hardness that was correlated with physicochemical characteristics. Grains with hard endosperms tend to present higher real density, lower flotation index and higher percentage of coarse particles after milling. The opposite pattern was met for intermediary hard kernels.

\section{AKNOWLEDGMENTS}

The financial resources for the conduction of this study were supported by the project BioAgroPar financed by FINEP, SETI/PR, and Fundação Araucária/PR; and by $\mathrm{CNPq} /$ Brazil.The authors thank to the Coordenação de Aperfeiçoamento de Pessoal de Nivel Superior (CAPES) for scholarships.

\section{RESUMO}

Esse trabalho teve o objetivo de caracterizar vinte variedades de milho crioulo cultivadas na região dos Campos Gerais (Estado do Paraná) em relação a sua composição química (umidade, cinzas, proteína, extrato etéreo, fibra alimentar e amido) e propriedades físicas (peso de 1000 grãos, densidade real, índice de flotação, granulometria e cor) Além disso, foi feito o processamento dos grãos em escala de laboratório para a extração do amido, sendo mensurado o teor de proteína. Foram avaliados os conteúdos de amilose e o perfil viscoamilográfico. Os resultados mostraram que os milhos apresentaram diferentes composições químicas e proporções pericarpo/endosperma/ gérmen e consequentemente podem ter diferentes aplicações industriais e interesse ao melhoramento de plantas.

\section{REFERENCES}

Almeida-Dominguez, H. D.; Suhendro, E. L; Rooney, L. W. (1997), Factors Affecting Rapid Visco Analyser Curves for the Determination of Maize Kernel Hardness. Journal of Cereal Science, 25, 93102. 
AOAC (2000), Official methods of analysis of AOAC international. $17^{\text {th }}$.ed. Washington.

Birol, E.; Villalba, E. R.; Smale, M. (2007), Farmer Preferences for Milpa Diversity and Genetically Modified Maize in Mexico. Washington: International Food Policy Research Institute, pp. 44.

Blazek, J. (2008), Role of amylose in structure-function relationship in starches from Australian wheat varieties. Doctor of Philosophy, Thesis, University of Sydney, Sidney.

Câmara, R. J. (2005), Cultivares crioulas de milho (Zea mays, L.) em sistema de produção orgânico Desempenho agronômico das plantas e composição química das sementes. Mestrado em Agronomia Dissertação, Universidade do Oeste do Paraná, Marechal Cândido Rondon, Paraná.

Cereda, M. C. et al. (2001), Propriedades gerais do amido. ed. Fundação Cargill, CAMPINAS, pp. 50-60.

cruz, j. c.; konzen, e. a.; pereira filho, i. a.; marriel, i. e.; cruz. i.; duarte, j. o.; oliveira. m. f.; alvarenga, r. c. (2006), Produção de Milho Orgânico da Agricultura Familiar. In-Ministério da Agricultura $e$ Abastecimento. Circular Técnica, pp. 1-17.

Demiate, I. M.; Konkel, F. E.; Pedroso, R. A. (2001), Enzymatic determination of starch in doce de leite using dialysis. Ciência e Tecnologia de Alimentos, 21, 339-342.

Dowd, M. K. (2003), Improvements to laboratory-scale maize wet-milling procedures. Industrial Crops and Products, 18, 67-76.

Fowler, C.; Hodgkin, T. (2004), Plant genetic resources for food and agriculture: Assessing global availability. Annual Review of Environmental Resources, 29, 143-179.

Fox, S. R.; Johnson, L. A.; Hurburgh, C.R.; DorseyRedding C.; Bailey T. B. (1992), Relation of grain proximate composition of physical properties to wetmilling characteristics of maize. Cereal Chemistry, 69, 191-197.

Gibbon, B. C.; Larkins, B. A. (2005), Molecular genetic approaches to developing quality protein maize. Trends in Genetics, 21, 227-233.

Gibbon, B. C.; Wang, X.; Larkins, B. A. (2003), Altered starch structure is associated with endosperm modification in Quality Protein Maize. Proceedings of the National Academy of Science of United States of America, 100, 15329-15334.

Gonçalves, R. A.; Santos, J. P.; Tomé, P. H. F.; Pereira, R. G. F. A.; Ascheri, J. L. R.; Abreu, C. M. P. (2003), Rendimento e composição química de cultivares de milho em moagem a seco e produção de grits. Ciência e Agrotecnologia, 27, 643-650.

Hou, H. X.; Dong, H. Z.; Lui, C. F.; Zhang H. (2008), Relationships Between Some Physicochemical Properties of Starches from Maize Cultivars Grown in East China. Starch/Stärke, 60, 305-314.
IAL (1985) - Normas Analíticas do Instituto Adolfo Lutz: Métodos Químicos e Físicos para Análise de Alimentos. São Paulo: $3^{\mathrm{a}}$ ed, pp.302-30.

Ji, Y.; Seetharaman, Y. J. K., White, P. J.(2004), Optimizing a small-scale corn starch extraction method for use in the laboratory. Cereal Chemistry, 81, p. 55-58.

Jiang, H. Y.; Zhu, Y. J.; Wei, L. M.; Dai, J. R.; Song, T. M.; Yan, Y. L. Chen, S. J. (2007), Analysis of protein, starch and oil content of single intact kernels by near infrared reflectance spectroscopy (NIRS) in maize (Zea mays L.). Plant Breeding. 126, 492-497.

Lojano-Alejo, N.; Carrillo, G. V.; Pixley, K..; PalaciosRojas, N.(2007), Physical properties and carotenoid content of maize kernels and its nixtamalized snacks. Innovative Food Science and Emerging Technologies, 8, 385-389.

Lopes-Filho, J. F. (1997), Moagem úmida do milho para produção de amidos e subprodutos. Boletim SBCTA, 31, 42-47.

Lucchin, M; Barcaccia, G; Parrini, P. (2003a), Characterization of a flint maize (Zea mays L. convar. Mays) Italian landrace: I. Morphophenological and agronomic traits. Genetic Resources and Crop Evolution, 50, 315-327.

Mauricio, R. A. S.; Figueroa, J. D. C.; Taba, S.; Reyes, M. L. V.; Rincón, F. S.; Mendoza, A. G. (2004), Characterization of maize accessions by grain and tortilla quality traits. Rev. Fitotec. Mexico, 27, 213222.

Miranda, G. V.; Souza, L. V. De; Santos, I. C. Dos; Mendes, F. F. (2007), Resgate de variedade crioulas de milho na região de Viçosa-MG. Revista Brasileira Agroecologia, 2, 1145-1148.

Mizuma, T; Kiyokawa, Y.; Wakai, Y. (2008), Water Absorption Characteristics and Structural Properties of Rice for Sake Breweering. Journal of Bioscience and Bioengineering, 106, 258-262.

Narvaéz-González, E. D.; Figueroa-Cárdenas, J De D.; Taba, S.; Tostado, E. C.; Peniche, R. A. M.; Sánchez, F. R. (2006), Relationships between the microstructure, physical features and chemical composition of different maize accessions from Latin América. Cereal Chemistry, 83, 595-604.

Nelles, E. M.; Dewar, J.; Bason, M. L.; Taylor, J. R. N. (2000), Maize Starch Biphasic Pasting Curves. Journal of Cereal Science, 31, 287-294.

Pereira, R. C.; Davide, L. C.; Pedrozo, C. A.; Carneiros, N. P.; Souza, L. R. P.; Paiva, E. (2008), Relationship between structural and biochemical characteristics and texture of corn grains. Genetics of Molecular Research, 7, 498-508.

Philippeau, C.; Monredon, F. Le D. De; MichaletDoreau, B. (1999), Relationship between ruminal starch degradation and the physical characteristics of corn grain. Journal of Animal Science,.77, 238-243. 
Posner, E. S. (1985), The technology of wheat germ separation in flour Mills. Association of Operative Millers. 4577-4592.

Ribeiro, E. P.; Seravalli, E. A. G. (2004), Química dos Alimentos. 1. ed. São Paulo: Edgard Blücher, pp. 184.

Salgo, A.; Juhasz, R. (2008), Pasting Behavior of Amylose, Amylopectin and Their Mixtures as Determined by RVA Curves and First Derivatives. Stärke, 60, 70-78.

Salinas, M. Y.; Bustos, F.; Gomez J. H. (1992), Comparación de métodos para medir la dureza del maíz (Zea mays L.). Archivos Latinoamericanos de Nutrición, 42, 59-63.

Schmildt, E. R; Krause, W; Cruz, C. D. (2006), Melhoria da eficiência dos experimentos de indicação de cultivares de milho. Ciência e Agrotecnologia. 30, 72-80.

Schoch, T. J.; Maywald, E. C. (1968), Preparation and properties of various legume starches. Cereal Chemistry, 45, 564-573.
Seetharaman, K.; Tziotis, A.; Borras, F.; White, P. J.; Ferrer, M.; Robutti, J. (2001), Thermal and functional characterization of starch from Argentinean corn. Cereal Chemistry, 8, 379-386..

SILVA, F. de A. E. (2004), Assistat versão 7.1 beta. Departamento de Engenharia agrícola do CCTUFGC, Campina Grande - PB.

Trindade, C. C. (2006), Sementes crioulas e transgênicos. Uma reflexão sobre sua relação com as comunidades tradicionais. Trabalho apresentado no XV Congresso Nacional do Conpedi, 15-18 Nov, Manaus, Amazonas.

Wickramasinghe, H. A. M.; Takigawa, S.; Endo, C. M.; Yamauchi, H.; Noda, T.(2009), Comparative analysis of starch properties of different root and tuber crops of Sri Lanka. Food Chemistry, 112, 98103. 